\title{
"Local self-regulation between democracy and hierarchy. Varieties of structure and values". Digital Mercator Workshop of the DFG Research Unit 2757/Local Self-Governance in the context of Weak Statehood in Antiquity and the Modern Era (LoSAM) from 18-19th March 2021
}

\author{
Anna Si-Lu Hauser · Janneke Tiegna \\ Accepted: 25 June 2021 / Published online: 19 July 2021 \\ (C) The Author(s) 2021
}

Across various disciplines, the concepts of self-governance and self-organisation generally carry positive connotations. Self-governance and self-organisation play a crucial role in the provision of public services from non-government and nonmarket actors and are thus vital driving forces for international development cooperation. International capacity building efforts further demonstrate that international development organisations consider self-organisation as a panacea for successful development. Historical and present examples of social movements further show the potential of self-organisation as a democratic force for a better future. Self-governance and self-organisation, which are often closely linked to concepts of democracy and civil society, are thus perceived as being the only fair and equitable structure.

Yet, numerous anti-democratic movements show that self-governance and selforganisation also bear negative connotations. To reveal the diversity of and potential contradictions within self-governance and self-organising groups, the DFGfunded Research Unit Local Self-Governance in the context of Weak Statehood in Antiquity and the Modern Era (LoSAM) organised a Mercator Workshop from 18-19 March 2021 with guests from Austria, Germany, India, Libya and the US. This workshop, organised by LoSAM Mercator fellow Dieter Neubert and LoSAM coordinator Christoph Mohamad-Klotzbach, focused on regulations and the actors' guiding values legitimising particular self-regulations in force.

\footnotetext{
Anna Si-Lu Hauser $(\bowtie)$

Institute for Cultural Studies of East and South Asia-Sinology, University of Würzburg, Am Hubland, 97074 Würzburg, Germany

E-Mail: anna_si-lu.hauser@uni-wuerzburg.de

Janneke Tiegna

Institute of African Studies, University of Leipzig, Beethovenstraße 15, 04107 Leipzig, Germany

E-Mail: Janneke.Tiegna@uni-leipzig.de
} 
The first presentation by Anupama Roy (Jawaharlal Nehru University Delhi) and Ujjwal Kumar Singh (University of Delhi) was on the topic "Pathalgadhi movement and the question of "weak state-hood"' in the east Indian Jharkland, a state with a considerable tribal population. As a so-called scheduled area, Jharkland did not entirely fall under the Indian Constitution and, as a result, land laws initially recognized the customary rights of the tribal population and their self-regulated use of land. However, the state's proposal to integrate the scheduled area gave rise to local resistance, which manifested in the Pathalgadhi movement. Villagers installed stone slabs, so-called pathals, to mark the boundaries of their village and controlled the village entries. Whereas pathals traditionally served as memorial slabs, during the Pathalgadhi movements, the pathals were inscribed with constitutional provisions. Anupama Roy and Ujjwal Kumar Singh set out how the self-regulation of the tribal population inserted competing logics of state in these regions, with the state playing a protective and repressive role at the same time. In addition, they explored the mobilization of the tribal population as processes through which stateness was imitated in contexts where the tribal population did not recognize the state. The Pathalgadhi movement gave insights into the complex world of states at the local level. Anupama Roy and Ujjwal Kumar Singh showed how questions of relationships among institutions locked in contestation over power, and also addressed questions pertaining to patterns of historical development of political authority, in a context where tradition and modernity collide.

The second presentation "What is 'local' and what is 'self' in local self organizations?-And how does self-regulation work effectively?", held by Gabriele Beckmann (University of Applied Sciences for Intercultural Theology Hermannsburg), shifted the perspective to macro-level learnings from three self-help groups in the eastern lowlands of Bolivia. Varying degrees regarding the effectiveness of and compliance to formal and informal rules in these groups gave rise to the question of what enables or hinders effective long-term cooperation within self-help organisations. The example of a 'successfully failing case', in which the self-help group had not achieved self-sustainability due to corruption and mismanagement and was yet kept alive by constant donations, demonstrated the entanglement of conflicting perspectives, expectations and objectives. The goal of capacity building was not achieved, but due to incessant donations, members of the self-help group had little incentives to change practices. Gabriele Beckmann concluded that the 'local' was reflected in the practice of cooperation, given that the group members acted as knowledgeable actors rather than external development advisors. The 'self', in turn, manifested in the organisational work in process, i.e. by sharing benefits according to internally set distribution rules, accompanied with transparent, acceptable and just negotiations. The discussion confirmed the complexity of understanding selforganisation with other examples in which self-organisation conflicts with external support organisations. Cases of successfully failing organisations, which receive international support not because of their effectiveness, but rather because of their positive image are widespread. This in turn discriminates against groups that are effective but do not enjoy a positive image, evoking the impression that international development organisations use self-organisation mainly for 'window-dressing'. 
The first workshop day ended with a presentation by Amy Cooter (Vanderbilt University) about "US Domestic Militias' Intersections with Government and Authority: How a 'sociology of individualism' informs their praxis". Amy Cooter dealt with U.S. militias in Michigan and the paradox that they saw themselves as an extension of the government even as they maintained a suspicious and sometimes overtly hostile stance toward the government. Militia members believed that the individual should be the ultimate authority for decisions and that it was every "real" American's responsibility to maintain the integrity of their own communities. As a result, these militias resented taxes and supported privatization. They were less hostile towards local government officials as they believed that local officials were better attuned to local needs, whereas federal officials were considered too distant to represent the local communities. Consequently, their trust in the state varied with different government levels, which in turn explained their actions and responses to perceived acts of government overreach. Amy Cooter concluded with the observation that the militia members' shared worldview was heavily shaped by the intersections of masculinity, whiteness, and nationalism, although many genuinely strived to be inclusive and egalitarian. The members saw their wariness as increasingly justified over time, and some groups used this as a justification for violent plots.

On the second workshop day, the focus shifted to the African continent. The first presentation was held by Georg Klute (University of Bayreuth) about "Competing TimeSpaces and Territorialisation from Below. Jihadi-Governance in the Sahara", in which he discussed two arguments in the field of politics among Tuareg rebel movements and jihadi groups in Mali and Niger. In a first step, Georg Klute presented his arguments on competing TimeSpaces in guerrilla warfare. Time and space are relative social and cultural categories, which are permanently constructed and deconstructed. With the example of guerrilla warfare, Georg Klute further illustrated competing concepts of time and space between the attacker and the attacked. As he observed, guerrillas changed their concept frequently and were characterised by adhoc mobilization and a high degree of mobility throughout attacks and retreats. Their warfare included constant redefinition of time and space, e.g. extending the war by strategic waiting. The ability to impose concepts of time and space made Guerrilla warfare successful, which the army often attempted to imitate. In addition, Georg Klute showed the emergent forms of political organisation. With the proclamation of the independent Azawad in Mali in 2012, the processes of territorialisation accelerated in Southern Sahara. Mali and France tried to recapture the north, while jihadists established new and alternative orders with local regulations, taxes, education, health, import and export. Today the borders are better controlled than during colonialism with the stationing of international forces. Mali and Niger were highly militarised, yet the jihadi groups organised, administered, and governed large parts of Mali's northern region outside the control of Mali's government and its allies. Georg Klute illustrated in his presentation that competing time-spaces corresponded to different political orders.

The following presentation by Thomas Hüskens and Amal Obeidi (both University of Bayreuth) about "Cyrenaica Contested: Politics, Identity and Justice in Times of Turmoil" addressed the making of identity as well as the politics and practices of justice in the context of a highly dynamic political regime during a restive pe- 
riod. Thomas Hüskens described the current political situation in Cyrenaica, eastern Libya, with the concept of heterarchy. As opposed to hierarchy, heterarchy refers to a plural political constellation, in which state actors at the local, regional, national and global level share sovereignty with non-state actors. In contrast to the concept of weak or fragmented statehood, heterarchy applies a non-normative description to the constellation of state and non-state actors. In the case of Cyrenaica, Thomas Hüskens observed that heterarchy produced plural orders ranging from cooperation and entanglement to competition and conflict. Amal Obeidi's research on identity expanded on this concept. She identified three non-state actors coexisting with state institutions, i.e. tribal groups, civil society and armed groups. Tribal groups played an important role in Cyrenaica, as they provided traditional mechanisms of selforganisation to remedy local conflicts. However, cases in which tribes turned into armed militias and took over state property showed that tribal groups could also evolve into sources of conflict. The role of the second actor, civil society organisations, began to increase after the end of the Gadhafi regime in 2011 and, given the early development stage, was facing problems regarding functions and work. The third actor, armed groups, emerged in the power vacuum that resulted from the collapse of the military and police, and played an ambiguous role. While some armed groups acted under the auspices of state authorities, others adhered to the tribal, geographical or ideological basis of their formation and exerted political pressure on behalf of specific stakeholders. Hence, armed groups also became a source of threat, challenging the Libyan state and the process of state building. The discussion revealed that actors could be members of tribal groups, civil society organisations and armed groups at the same time and thus incorporated multiple layers of identity. As a result, actors would frequently switch between different practices, which complicated understanding their position towards other groups and the state.

The presentation "Contesting or complementing the municipality: Self-regulations within the occupation of Reclaim the City" by Antje Daniel (University of Vienna) shifted the perspective from turbulent and violent contexts in Northern and Western Africa to the problem of social housing in South Africa. Guided by the concept of heterotopia as according to Foucault, Antje Daniel investigated self-organisation among the members of the Woodstock occupation in Cape Town who had been evicted from their homes as a result of increasing gentrification. With regard to local-state relationships and similar to the previous presentations, Antje Daniel's case study depicted ambivalent relationships between the self-organising group and state agents. Although the movement occupied the house illegally, the municipality showed support by providing free electricity and water. During public protests, however, the movement and the municipality appeared as opponents, as occupants demonstrated against the municipal housing policy. Consequently, the local-state relationship switched between spaces; within the occupied house, the relationship between Reclaim the City and the municipality was characterised by complementarity and cooperation, whereas 'on the street', the actors entered into an adversarial relationship. The discussion extended the example of Reclaim the City in South Africa to occupations with similar goals but in places with different conditions. In light of gentrification as a global phenomenon, Antje Daniel argued that the case of Cape Town qualifies for comparison with cases in the global North. 
The last presentation by Matthew Sabbi, Alexander Stroh-Steckelberg and Dieter Neubert (all University of Bayreuth) about "Legitimation strategies of councillors under national and global influence: How autonomous are local self-governance and local self-organization?" set the focus on a hardly discussed topic of councillorled farmer self-help groups in rural Ghana and their everyday processes of legitimization towards state and outside entities. It was demonstrated that councillors had overlapping roles in the different structures and multiple legitimation roles. For instance, on the one hand councillors enhanced the credibility of their self-organized groups towards outside entities including financial institutions, while on the other hand councillors were the preferred brokers for external development actors. In this process of legitimization, the self-help groups adapted to formal state regulations, although councillor-led groups used their state links as a platform for critiquing local state projects. Matthew Sabbi, Alexander Stroh-Steckelberg and Dieter Neubert concluded that it was hard to clearly differentiate between local self-organization and the state, particularly as global notions of self-help, such as preferences of international donors, interfered. In fact, in the case of Ghana, they observed mutual instrumentalization by local self-organisation and councillors on the one hand and the state and development organizations on the other hand.

The final discussion did not only provide a summary of findings across the various presentations, but also presented a starting point for further research, extending investigations on self-organisation and self-regulation in new directions. Dieter Neubert summarised his observations along two major perspectives, i.e. the outside relations of local actors and the internal structure of self-organising groups. On the one hand, numerous presentations demonstrated that conflicts did not only arise between the locality and the state, but also among different local actors. The broad variety of organisational structures, many of which mimicked state structures to a certain extent, made it difficult to assess where the local ends and the state begins. It became clear that the boundary between the locality and the state was blurred.

Pointing to the various intersections between security, government and opposition, Christoph Mohamad-Klotzbach concluded that by asking "What is the State?" also required considering with whom state actors interact. Evaluating differences and similarities may also contribute to comprehending how identities and group belonging manifest for internal members and external actors. Hans-Joachim Lauth proposed to include further criteria that evaluate the success of self-organisation. What is successful self-organisation and what are some possible criteria for success?

Finally, Dieter Neubert assumed that historical research on self-organisation may come to similar conclusions, thus showing more parallels between antiquity and modernity than previously assumed. Although accessing relevant data in classic historical research is challenging, more diachronical research that includes antiquity, the middle ages and modernity has the potential to reveal multiple parallels and path dependencies regarding self-organisation and local-state relationships. Rene Pfeilschifter (ancient historian and Speaker of the DFG Research Unit) reaffirmed this assumption and underscored that in his field of research, too, the research categories adopted are useful and reveal similar phenomena, which indeed enable a comparative research strategy that includes different historical epochs. 
Funding Open Access funding enabled and organized by Projekt DEAL.

Open Access This article is licensed under a Creative Commons Attribution 4.0 International License, which permits use, sharing, adaptation, distribution and reproduction in any medium or format, as long as you give appropriate credit to the original author(s) and the source, provide a link to the Creative Commons licence, and indicate if changes were made. The images or other third party material in this article are included in the article's Creative Commons licence, unless indicated otherwise in a credit line to the material. If material is not included in the article's Creative Commons licence and your intended use is not permitted by statutory regulation or exceeds the permitted use, you will need to obtain permission directly from the copyright holder. To view a copy of this licence, visit http://creativecommons.org/licenses/by/4. $0 /$. 